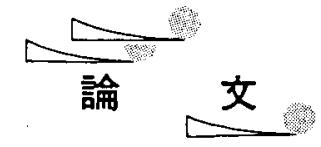

\title{
開口端を有するダクトにおける脈動流に関する研究*
}

\author{
弓野 崇**, 岩澤 敦***, 加藤 康晴 ${ }^{\dagger}$, 谷田 好通 ${ }^{\dagger}$
}

\section{Pulsating Flows in a Two-Dimensional Duct with Sudden Expansion}

Takashi Yumino, Atsushi Iwasawa, Yasuharu Kato and Yoshimichi TANida

\begin{abstract}
The purpose of the present paper is to study the characteristics of flow and gas exchange in the pulsating flow in the respiratory net work both by flow visualization and by numerical simulation.

The pulsating flow in a two-dimensional duct was visualized by the smoke-wire method, and its time-dependent velocity profile in the duct was measured with reasonable accuracy. The behavior of the pulsating flow around the duct intake was observed by the tobacco -smoke method and it was shown that the breathing air causes the streaming that brings about gas exchange.

The numerical results confirmed the experimental results and predicted the behavior of gas diffusion at the intake.

Key words: Pulsating flow, Gas exchange, High-frequency ventilation, Tobacco-smoke method
\end{abstract}

\section{1.まえがき}

高等動物の主な呼吸器は肺であるが, それは多分岐す る気道とその末端にある無数の肺胞よりなっている11. 気道は管状で鼻口に始まり鼻，鼻腔，咽頭，喉頭をへて 気管, 気管支, 細気管支等々から肺胞管へと倍々に分岐 して肺胞に達する。肺胞は伸縮性のある微小な袋状のも ので, 横隔膜と胸壁 (助骨) の移動により膨張, 収縮す ることによって鼻口を通して外気を吸入し，肺胞気を排 出する.

呼吸器系を流体力学的に見ると, 流れは時間平均流量 が 0 の脈動流であり，それが複雑な分岐管で生ずる，内 田は直円管（直径 $d$ ）における脈動流（振動数 $f$ ) を解析 的に調べ, 脈動流の挙動は無次元振動数 $\alpha=(d / 2)$ $\sqrt{2 \pi f / \nu}(\nu$ は流体の動粘性係数)に依存することを示し $た^{22}$. 生理学においてはこの無次元数をウォーマース リー(Womersley) 数とょんでいる。次に, 角田らは曲 がり管における脈動流を可視化実験と数值解析により調 べ, 脈動流においても流れ方向に軸をもつ一対の渦より

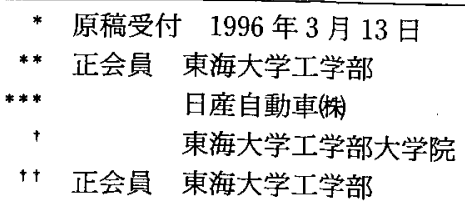

なる定常的な 2 次流れが生ずることを示した ${ }^{3)}$ 分㞳管 は丁度曲がり管を 2 個抱き合わせた構造をもつことから， やはり同様な 2 次流れが生ずる4 向に幾何学的に非対称であることから，脈動流では吐き 出し行程と吸い込み行程では流れも非対称となり, その 一周期にわたって時間平均すると, 定常的な 2 次的流れ が残る.これはストリーミングと呼ばれるもので5),これ により，流体粒子が管軸方向に非可逆的に移動して，流 体の強制的な移送・交換が行われる ${ }^{6)}$.さらに，分岐管に おいては，吸気の場合分岐部で流れの剝離・混合が生じ， 定常な場合でも直管におけるポアズィユ流れの数倍の圧 力降下が生ずることが示されているが4), 脈動流におけ る流れの挙動や圧力損失等の詳細は明らかでない.

一方，呼吸におけるガス交換に関しては，正常呼吸の 場合, 一回呼吸気量が気道容積の $1 / 3$ 程度であるにもか かわらず，肺胞気が排出されるが，このようながス交換 は分子拡散のみならず，上述の流れとの干涉によって効 率よく達成されると考えられる。直円管の定常流におけ る拡散に関しては Taylor 拡散 ${ }^{7)}$ が知られているが, 脈 動流に関しても理論的, 実験的に調べられている8 ${ }^{8) \sim 10)}$.し かし, 分岐管に関しては, Taylor 的拡散, 2 次流れ, ス トリーミング等が共存し，それらがどのような度合いで 拡散に影響しているか明らかでなく，限られた䉓囲に対 して脈動時の拡散が実験的に調べられているに過ぎな 
( $^{11,12)}$.さらに, 人工呼吸では 1 回の換気量を正常呼吸の 10 分の 1 程度に小さくして数 $\mathrm{Hz}$ 程度の高周波数の呼 吸法が採用されている. 高頻度換気 (High-Frequency Venti-lation: HFV) と呼ばれているが，このような高周 波数呼吸でも正常呼吸と同じ程度のガス交換が達成され ているが，その理由は十分に解明されていない(13),14).

上述のように, 呼吸器系においては, 気道に抢ける脈 動流とガス交換が注目されているが, 両者の相関につい てはまだ十分に明らかにされているとは言えない。一方， 鼻口に関しては今まであまり注目されていないが，ダク 卜開口端と考えられる鼻口も形状が非対称で, 吸気と呼 気とで流れの様相が大きく異なり，その一周期にわたっ て時間平均すると，定常的な 2 次的流れが残る. それに より新気と肺胞気とを効率よく交換する機能をもってい ると考光られる。 そこで, 本研究は全体計画としては, 鼻口と分岐管に㧍ける脈動流とガス交換を実験的, 数值 解析的に調べて各要素に扔ける有効拡散係数を評洒し, 呼吸器系のシミュレーションモデルを確立することを目 的とするが，まず本論文では鼻口に注目し，それをモデ ル化した開口端を有する 2 次元ダクトにおいて脈動流の 挙動を実験的, 数值解析的に調べる。なお, 本研究にお ける呼吸条件は高頻度呼吸に相当する。

\section{2. 実験}

\section{1 実験装置と実験方法}

実験装置は, Fig.1に示すように, タンク $(28 \times 28 \times 28$ $\mathrm{cm}$ 立方), 2 次元ダクト (断面: 高さ $10 \mathrm{~cm} \times$ 幅 $(2 \mathrm{~h})$ $3 \mathrm{~cm}$, 長さ $150 \mathrm{~cm})$ 预よび脈動流発生装置よりなる.夕 ンクおよびダクトは, 流れの可視化観察のために, 透明 プラスチック製である. 脈動流発生装置は, 単筒ピスト ン機関を改造したもので, 行程体積 $V_{T}$ (呼吸気量に相 当）は $459 \mathrm{~cm}^{3}$ である.ダクト開口端（空気取り入れ口） には, 外部の摫乱を防ぐために，側壁が取り付けられて いる.

実験は, 任意の周波数の脈動流を作って, 流れの可視 化（スモーク・ワイヤ法抢よびタバコ煙法）と熱線流速 計を用い, 流路幅方向断面 $(z=0)$ で計測を行った。実 験条件をTable 1 に示す.

ここで,

$$
\text { レイノルズ数: } R e=\frac{U_{0} \cdot 2 h}{\nu}
$$

$v:$ 空気の動粘性係数

平均流速振幅: $U_{0}=\frac{\pi f V_{T}}{A}$

$A$ : ダクト断面積

無次元振動数（ウォーマースリー数）

$$
\alpha=h \sqrt{\frac{2 \pi f}{\nu}}
$$

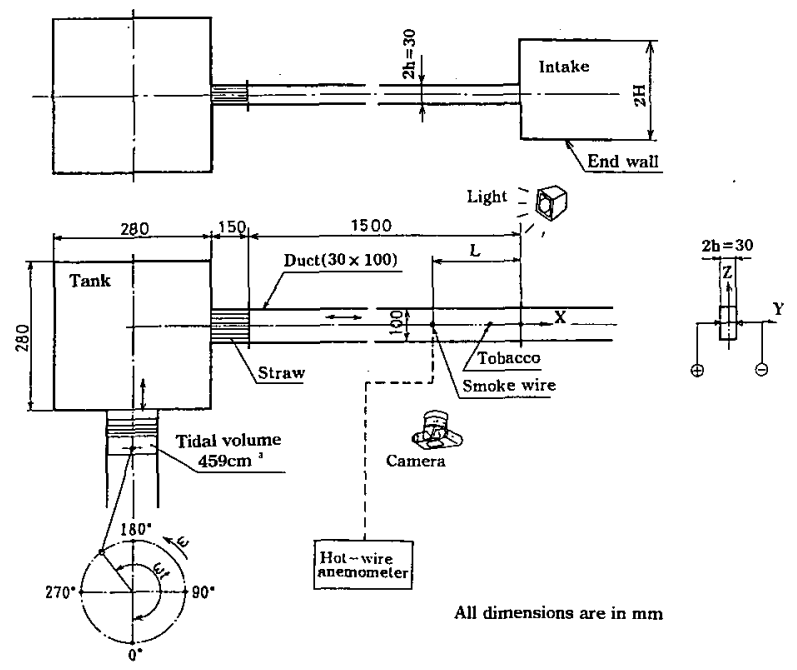

Fig.1 Experimental setup

\begin{tabular}{|c|c|}
\hline Wormersley number $\alpha$ & $3.96,4.84, \quad 5.59,6.84,8.83$ \\
\hline Reynolds number & $240, \quad 320$ \\
\hline Distance of endwall $\mathrm{H}$ & $9 \mathrm{~h}, \quad 13 \mathrm{~h}$ \\
\hline Measuring point $\mathrm{L} m \mathrm{~mm}$ & $100, \quad 150, \quad 750$ \\
\hline
\end{tabular}

Table 1 Experimental conditions

以下に実験法を簡単に述べる，なお，流れは双方向流 であるから，吐出し行程時を基準にして考えることにし， タンク側を上流，開口端側を下流とする。

ダクト内の脈動流の速度分布は, スモーク・ワイヤ法 抢よび熱線流速計によって測定した。 スモーク・ワイヤ 法では, 直径 $0.1 \mathrm{~mm}$ のタングステン線をダクト軸に直 角に流路幅一杯 $(30 \mathrm{~mm})$ に張り, それに流動パラフィ ンと灯油を $1 ： 1$ に混合したものを適当な量だけ塗布し， エンコーダ信号によって任意の位相角（下死点基準）で 通電して発煙させる。この場合, 暗室内でカメラのシャッ 夕を解放にし, 遅延回路を用いて適当な遅延時間でス卜 ロボを発光させ 1 本目のタイムラインを撮影する.さら 汇適当な遅延時間でストロボを発光させ, 2 本目の夕イ ムラインが得られ，その移動距離よりその点における流 速を求めることができる，一方，比較のために，熱線流 速計による測定も行った。しかし，流速が低い（0５0 $\mathrm{cm} / \mathrm{s}$ ) 上に, 脈動流であるから流速 0 の状態が必然的に 存在し, ピストンのビビリの影響やサイクル変動もある ので，3サイクルにわたって信号の平均化処理を行った。

ダクト開口端における流れの観察は, 主としてタバコ 煙法を用いて行い，スモーク・ワイヤ法も併用した。前 述の脈動流の特徴のために, タバコ煙の供給が困難で あったので,ダクト壁にあけた孔に紙巻きタバコを直接 ダクトに挿入した (開口端上流 $25 \mathrm{~cm}$ ). このため, 浮力 の影響が若干みられ, 変化が微小なダクト内のストリー ミングの観察はできなかった，開口端下流に生ずる渦を 
可視化する際には，スリット光線を下流側より照射して 観察，撮影を行った。撮影は写真撮影の他，ビデオ撮影 も行った.

\section{2.ダクト内眽動流の流速分布}

Fig.2に，スモーク・ワイヤ法と熱線流速計で測定した 流速の時間的変化の 1 例を示す. スモーク・ワイヤ法で 得られた結果は, 熱線流速計のものと比較的よく一致し ているが,やや時間遅れをもって変化している.これは, スモーグ・ワイヤ法の場合, 通電から発煙までの時間遅 れによるものと考えられる。このようにして得られた結 果より，流路断面における流速分布の脈動 1 周期におけ る時間的変化を求めたものを Fig.3 に示す.これは, 開口 端の影響をうけないダクト中央付近での速度分布であっ て, 吐き出し行程と吸い込み行程における速度分布は対 称であり，熱線流速計による測定結果（Fig.4 a) とほほ 一致している。図にみられるように，ウォーマースリー

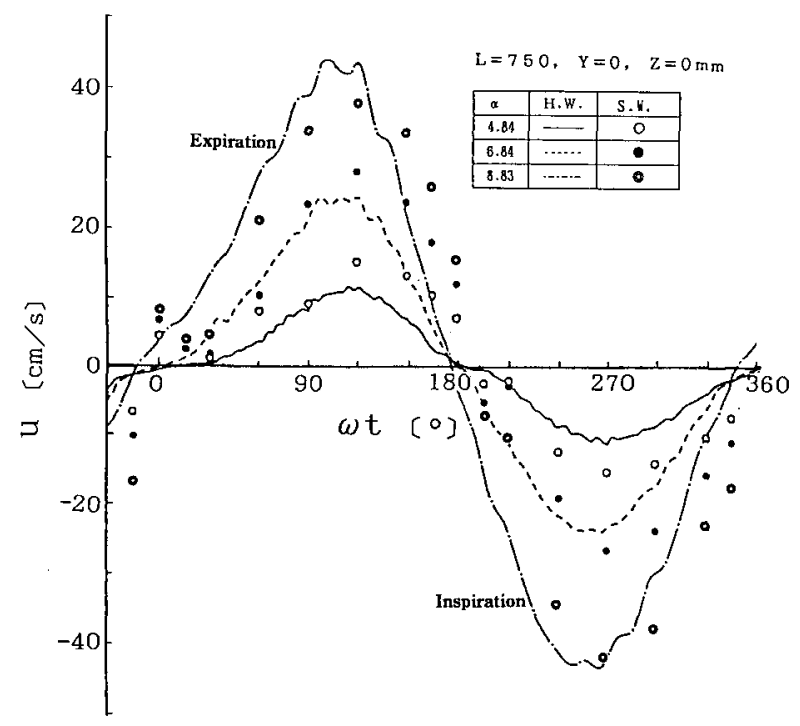

Fig.2 Time-dependent velocity profile

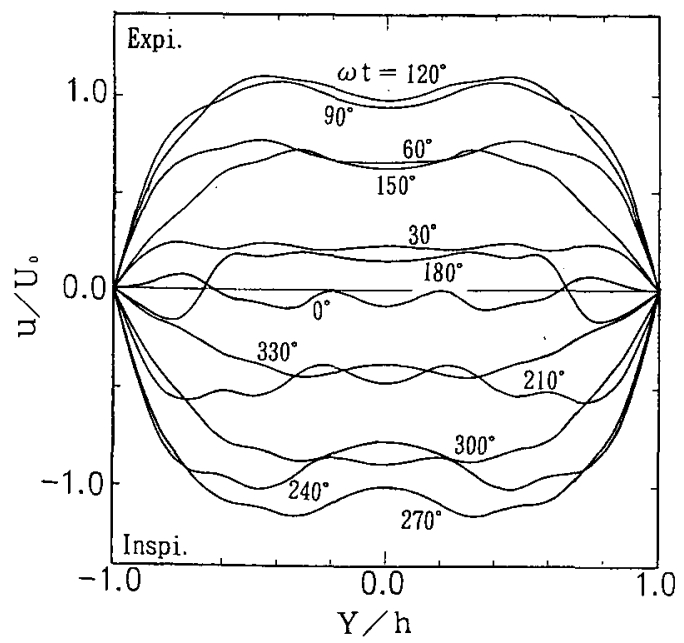

(a) $L=750 \mathrm{~mm}$

Fig.4 Time-dependent velocity profile (Hot-wire anemometer)
数 $\alpha$ が大きくなると, 粘性の影響が管壁付近に限定され てくるために，管中心付近で速度分布が一様になり，ま た管壁付近と管中心付近とで時間的位相差が顕著になっ て，流速が反位相で変化するようになる。一方，ダクト 開口端付近ではFig.4 bに見るように, 吐出し行程と吸 い込み行程における速度分布の対称性はくずれ, 吸い込 み流速が吐き出し流速より大きくなっている.これはダ クト開口部の端部に剥離渦が発生し, 流れがダクト中心 部付近に偏って流れるためと考えられる。これらの結果 は後述の数值計算結果と比較的よく一致している.

\section{3 ダクト開口端における眽動流の可視化}

本研究では主としてダクト開口端付近における流れの

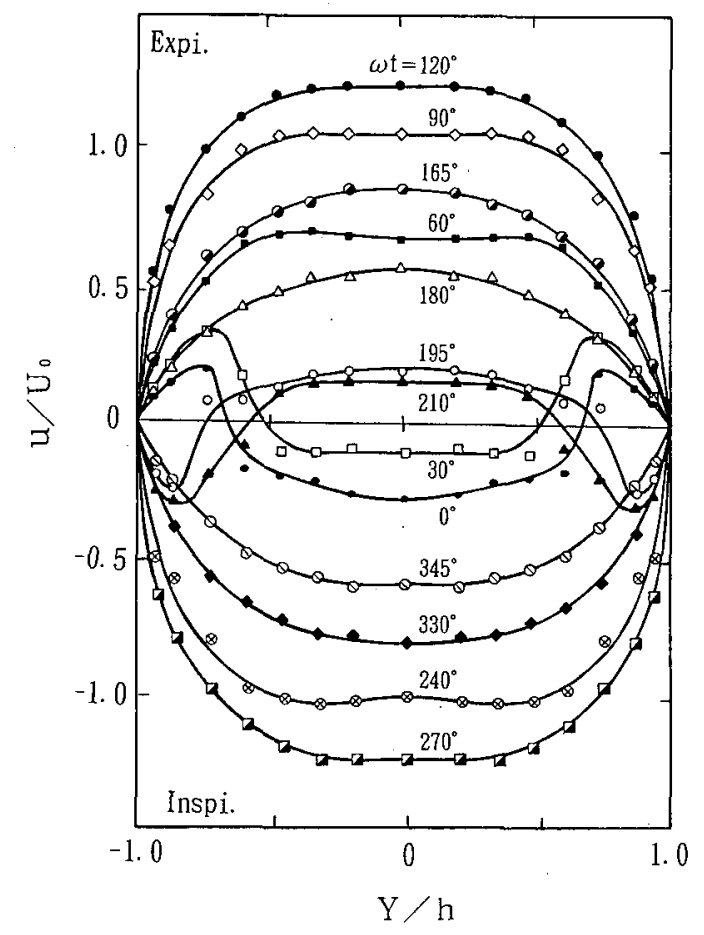

Fig.3 Time-dependent velocity profile $\alpha=4.84, U_{0}=12.0 \mathrm{~cm} / \mathrm{s}, \quad L=750 \mathrm{~mm}$

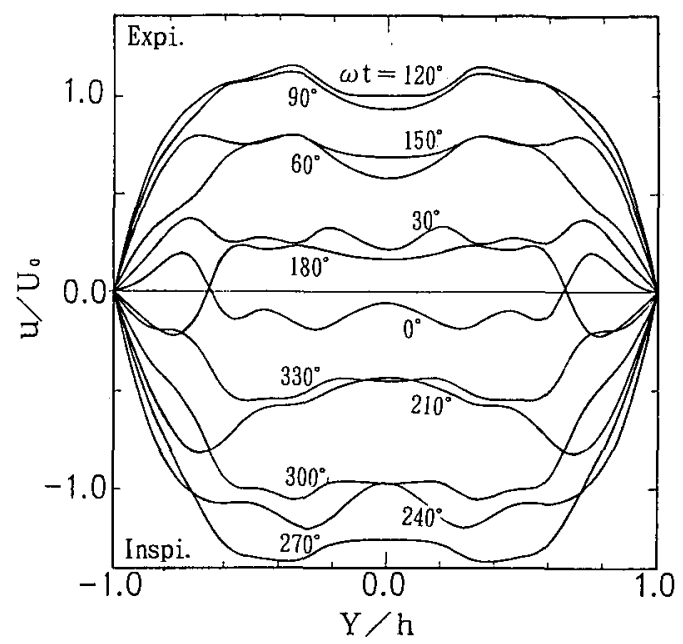

(b) $L=50 \mathrm{~mm}$ 


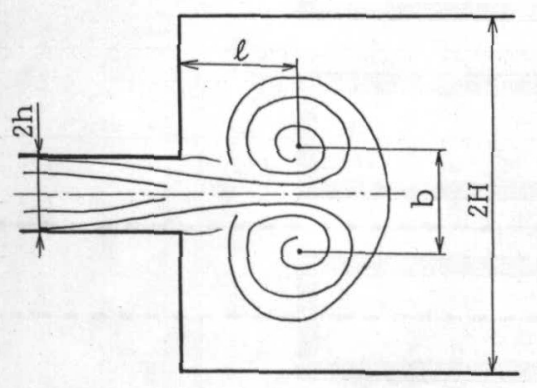

Fig.5 Schematic diagram of the intake

挙動に注目するが，剥離を伴う複雑な脈動流を熱線流速 計で測定することは難しく，またそれより流れを全体的 に把握することも困難であることから，ここでは可視化 によって流れを観察, 解析することにする.

Fig.5 に開口端における流れの概略図を示す.本実験で は, ダクト開口端下流に，下流側よりの䚌乱を防ぐため と数值計算結果とも比較することを考慮して, 側壁（間 隔 $2 H$ ) を設けている.

Fig.6 は, 下流側壁の間隔が広い $(H=13 h)$ 場合にお いて, 脈動 1 周期におけるダクト開口端における脈動流 をタバコ煙法によって可視化した場合を示す，吐き出し 行程 $\left(\omega t=0^{\circ} \sim 180^{\circ}\right)$ に入ると, ダクト開口端より流出 する流れは開口端の角で剥離し, 1 対の渦を形成する.こ の 1 対の渦は次第に成長し, 渦中心は下流に移動してゆ く. 脈動流が吐き出し行程から吸い込み行程 $\left(\omega t=180^{\circ}\right.$ $\sim 360^{\circ}$ ) に入ると, 渦の外側から開口端の角をまわって ジェット状の流れがダクト内に流入し, それとともに 1 対の渦は下流に押し出されて次第に減衰, 拡散して行く.

これに対して, 開口端下流に狭い側壁 $(H=3 h)$ を設 けた場合には, Fig.7 に示すように, 吐き出し行程で作ら れた 1 対の渦は下流へ䫓著に移動することなく, 吸い込 み行程においては周囲のジェット状の吸い込み流れに引 きずられるようにダクト内に吸い込まれる。このように， 渦の動きは側壁の間隔によって大きく変わるが, 側壁の 間隔が小さくなると, 側壁による鏡像効果により渦の移 動が抑制され, またダクト開口端下流における吸い込み 流速の増加と相まって, 渦があまり下流に移動すること なく, 再びダクト内に吸い込まれるようになると考えら れる。

Fig.8 は, 以上のような可視化写真より渦中心位置の時 間的変化を求めたものである.これを見ると, 上述のよ うに, 下流側壁の間隔が大きい場合には渦は下流に移動 して次第に消滅するが，下流側壁の間隔が小さくなると 渦は一旦下流に移動した後, 再び上流に移動しているこ とがわかる，渦が下流に移動する速度は, ダクト内の平 均流速の $13 \%$ 程度である.

以上の結果より, 開口端を有するダクトにおいては, 脈動流はその吐き出し行程で渦を生成・放出し, 吸い込 み行程で渦の周囲から外部の流体を吸い込んでおり, し
Expiration
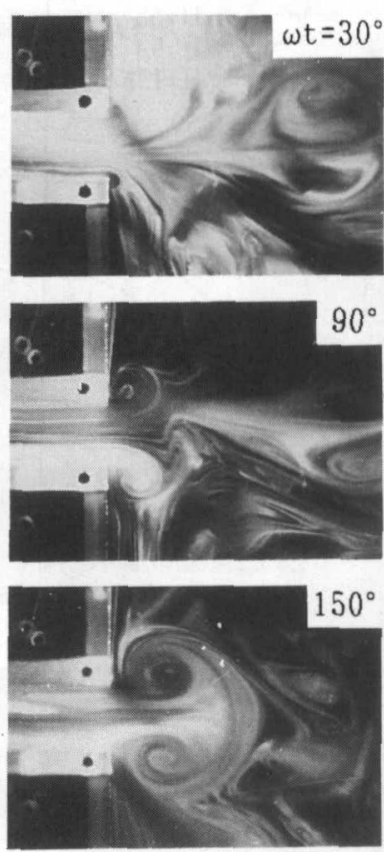

Inspiration
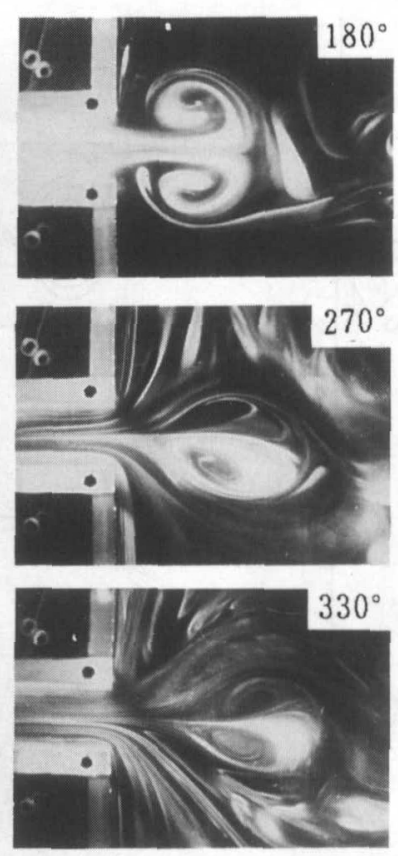

Fig.6 Flow pattern around the intake $\alpha=4.84, H=13 h$

Film: iso 400, Exposure: $1 / 30 \mathrm{~s}$ Lens aperture: 1.4

Expiration
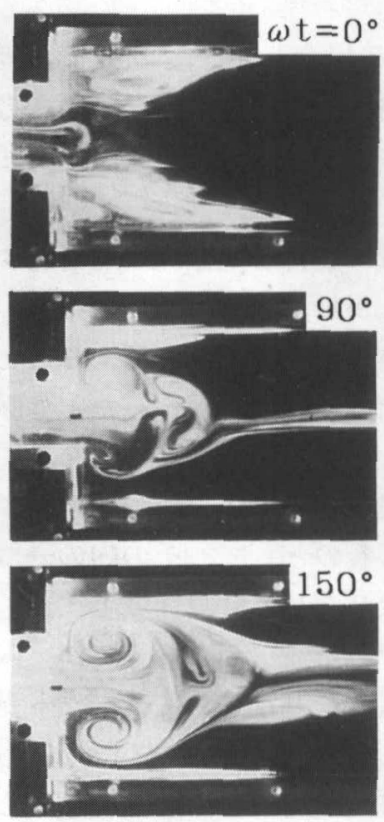

Fig.7 Flow pattern around the intake $\alpha=4.84, H=3 h$

Film: iso 400, Exposure: $1 / 30 \mathrm{~s}$ Lens aperture: 1.4

たがって吐き出し行程と吸い込み行程とでは非対称の流 れを形成している.これより鼻口においても定常的な 2 次的流れ（ストリーミング）が生じて，強制的なガス交 換が行われていると考えられる. 上述の可視化実験では, 


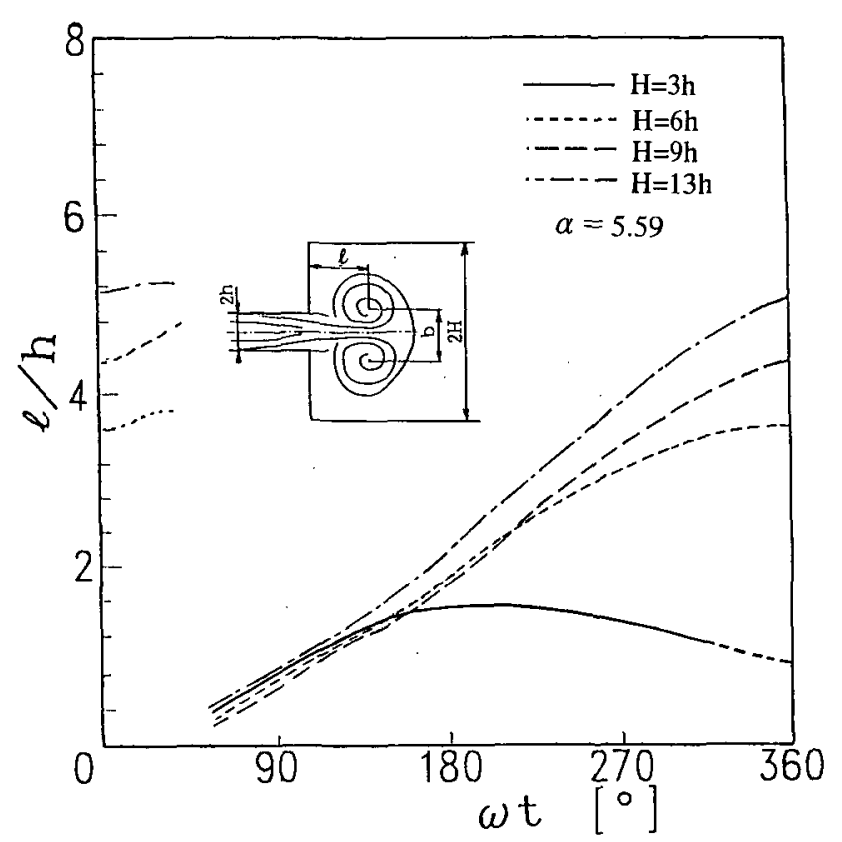

Fig.8 Axial location of the vortex center

脈動流によるストリーミングの強さやガス交換量を定量 的に求めることは困難であるので, それらを以下の数值 解析によって調べることにする。

\section{3. 数值解析}

\section{1 解析モデルと解法}

数值解析においても, 実験の場合と同様, 2 次元流れ場 を考元, 2 次元の非圧縮性・粘性流れに関する渦度輸送方 程式と渦度の式を有限体積法により差分化し ${ }^{15)}$, 過緩和 法により解いた。

解析モデルとしては，実験の場合と同様開口端を有す る 2 次元ダクトを考える.しかし，数㗄解析において， 開口端下流側に無限に相当するような領域を考えること は望ましくないこと，また領域を有限に限定したとき脈 動流の境界条件を与えることは難しいこと, などを考慮 して,Fig.9 に示すように鼻口がある間隔で無限個並んで 現象が周期的に変化しているものとして, その内の一つ の領域（図中，点線内）を取りだして計算領域とする。

Fig.10はそれを示したものである.

計算領域は, ダクトの半幅 $h$ を基準として, ダクト長 さ（X方向）を $100 h$ ，計算領域全体の長さを $120 h$ とし， ダクト開口端下流部の幅 $H$ は $3 h, 6 h, 12 h$ の 3 種類とし た.ここでは, 計算領域は等間隔格子で分割し, その分 割数は $X$ 方向に $600, Y$ 方向に 10 （ダクト内）とした. な押, 境界条件として, 無限上流 (境界 B 4) に 1 次元脈 動流の解, 無限下流 (B 6) に平行流条件, B 1 では $\phi=$ $0, \zeta=0$ を，B 3 では $\phi=\cos (2 \pi F t) ， \zeta=0$ と与えた。

\section{2 結果および考察}

\section{2 .1 ダクト開口端における眽動流の挙動}

Fig.11 に, 無限に長いダクト内の 1 次元脈動流の数值 計算結果を示す.ここで, 流速 $u$ は平均流速の振幅 $U_{0}$ で

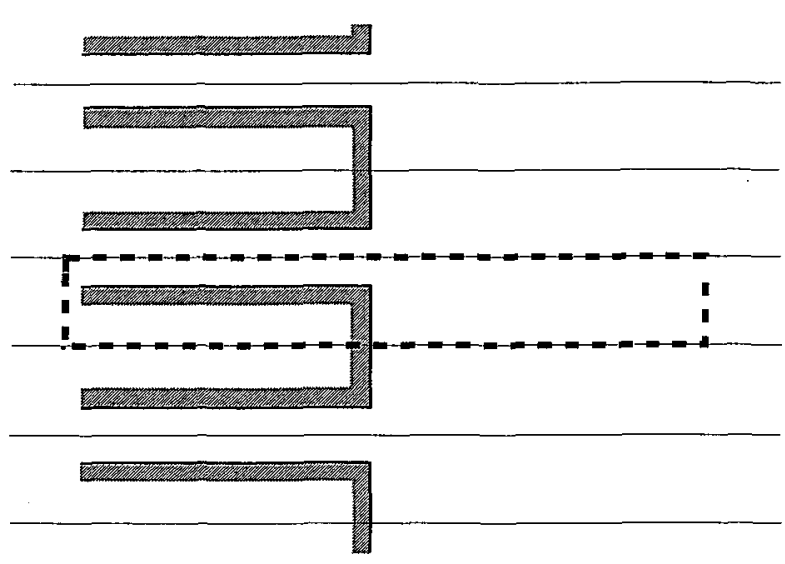

Fig.9 2D duct model

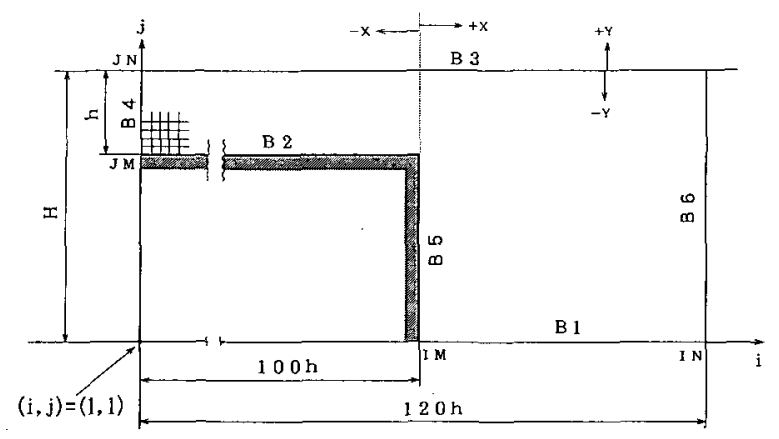

Fig.10 Numerical region

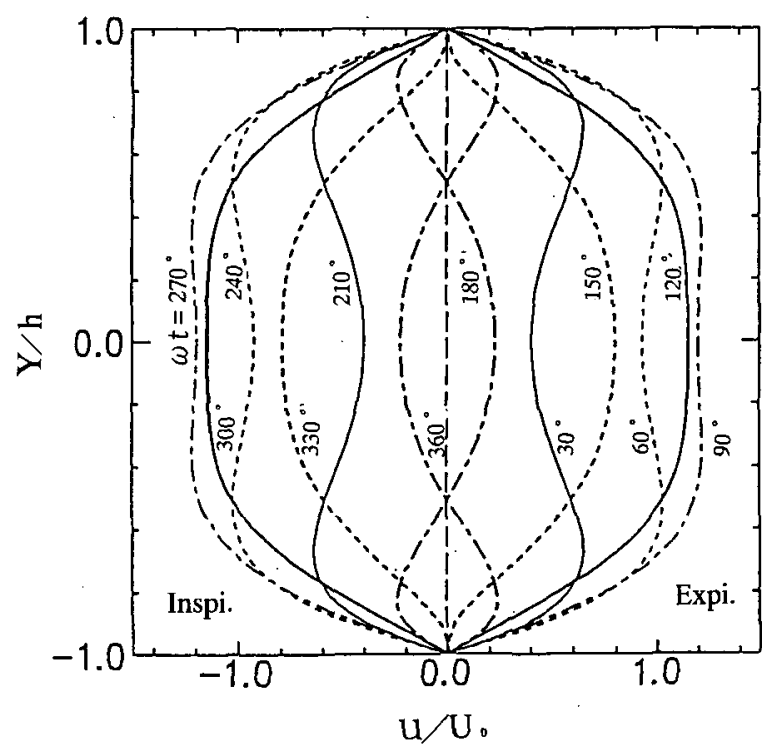

Fig.11 Time-dependent velocity profile by $1 \mathrm{D}$ numerical solution of pulsating flow in the infinity duct $\alpha=4.84, \operatorname{Re}=477$

無次元化しており，脈動の位相間隔 $30^{\circ}$ おきの流速分布 が示されている. 図中の位相 $180^{\circ}$ は吐き出し行程の終点

(以下, 上死点とする), $360^{\circ}\left(0^{\circ}\right)$ は吸い込み行程の終 点（以下，下死点とする）を示す。この数値計算結果は 1 次元脈動流の厳密解とよく一致しており,また第 2 章 
で述べたように，脈動流の特徵，すなわちダクト壁面付 近における逆流現象やダクト中心付近における流速の平 坦化などを見ることができる。

次に, 得られた 1 次元脈動流を, 開口端を有する 2 次 元ダクトの上流境界に境界条件として与えて計算する。 以下,一例として $H=3 h$ の場合の結果を示す.Fig.12 は 流線 (上半分)，渦度分布 (下半分) を示す。これょり， 吐き出し行程 (位相 $0^{\circ} \sim 180^{\circ}$ )において流れはダクトから 噴流状に噴出し，ダクト開口端の角で流れが剝離して渦 が生成される。渦度分布を見ると, ダクト開口端の角に

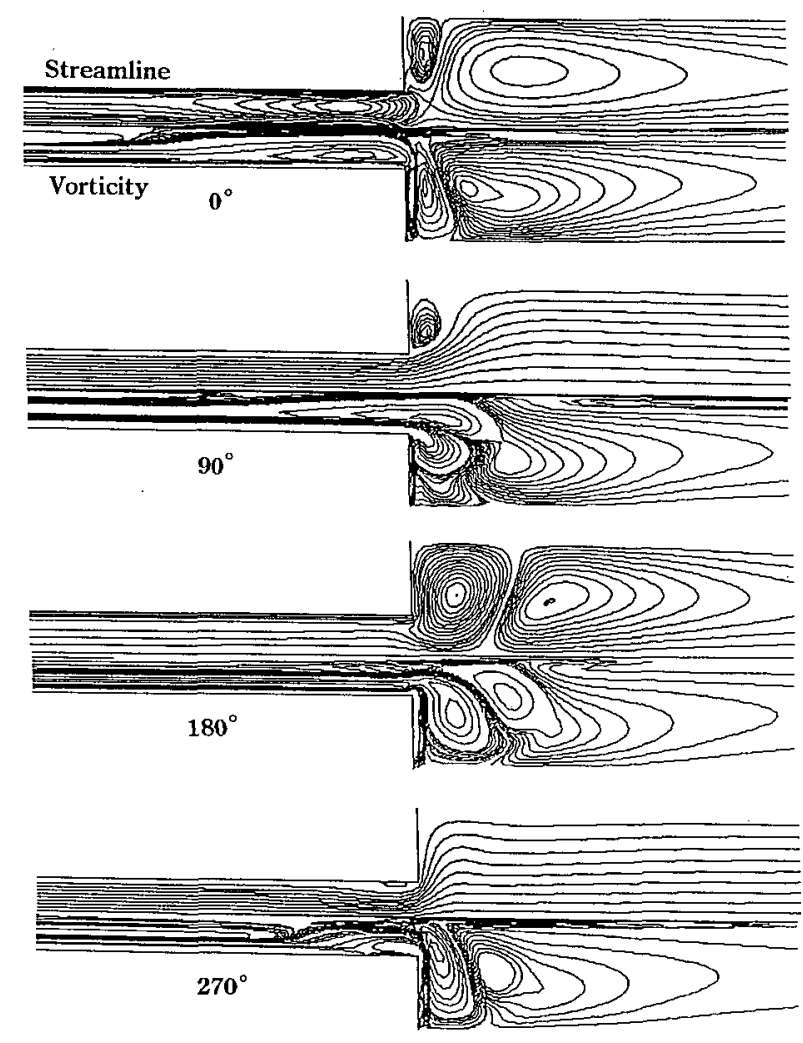

Fig.12 Streamlines (upper) and equivorticity contours (lower) $\alpha=6.84, \operatorname{Re}=477, H / h=3$
生ずる渦は強い右まわりの渦であるが，ダクト中心部に 左まわりの弱い渦が生じており，これらの渦が対になっ てダクト開口端下流に広がって行く，ついで，吸い込み 行程 (位相 $180^{\circ} \sim 360^{\circ}$ ) に入ると，ダクト開口端下流の壁 面側からダクト内へ強い吸い込み流れが生じ，開口端角 からダクト内にかけて流れの剥離泡が発生し，それに よってダクト中心部では流速が大きくなる．また，それ とともに，流路全体に広がっていた渦も一部吸い込まれ るが,ダクト中心部の左まわりの渦は孤立化して下流に 流されて行く，再び吐き出し行程に入ると，右まわりの 渦は新たにダクト開口端角に生ずる渦と合流して行く. 開口端における流れの挙動は, 流路や流れの条件が変 わっても基本的に大きな違いは現れなかった。これらの 結果は, 定性的に実験でえられたものと一致している.

\section{2 .2 ダクト内の流れに対する開口端の影響}

実験および数值計算の結果より，ダクト開口端で脈動 流は空間的, 時間的に非対称であって,いわゆるストリー ミングが生ずる.そこで，ダクト内流速分布の開口端に よる雨量を調べ, ストリーミングの強さとその存在する 範囲を評価してみる。

そこで, 上述の計算結果より, 開口端によるダクト内 流速（ダクト軸方向成分）の䄳みを調べた。その結果を 平均流速振幅 $U_{0}$ で流速 $u$ を無次元化して Fig.13に示 寸. 図 a は, 開口端よりの距離がかなり大きな位置 $(X /$ $h=-9.85)$ での流速であって, 開口端の影響をほとんど 受けておらず, 吐き出し行程と昅い込み行程でほほ対称 な分布を示している.しかし, 開口端に近づくにしたがっ て, 流速分布の対称性が失われてくる(図b). すなわ ち, 吐き出し行程ではあまり大きな変化は見られないが, 吸い込み行程では，西る位相でダクト壁面での流れの剥 離による逆流が生じ，ダクト中心部の流速を増大させる 結果, 吐き出し行程と吸い込み行程とで流速分布が非対 称となる.しかし, 開口端 $(X=0)$ では角をまわる流れ が強く加速されるために, 図 $\mathrm{c}$ のように見かけ上十分上 流の図 a に近い流速分布になっている。ここで，ダクト 上流の $X / h=-9.85$ の点を基準として, 各点における

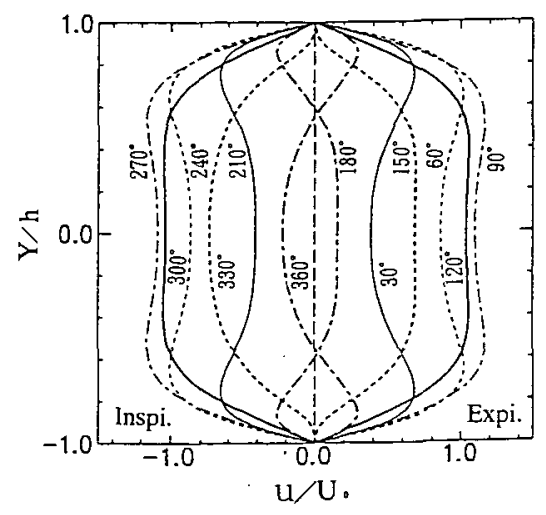

(a) $X / h=-9.85$

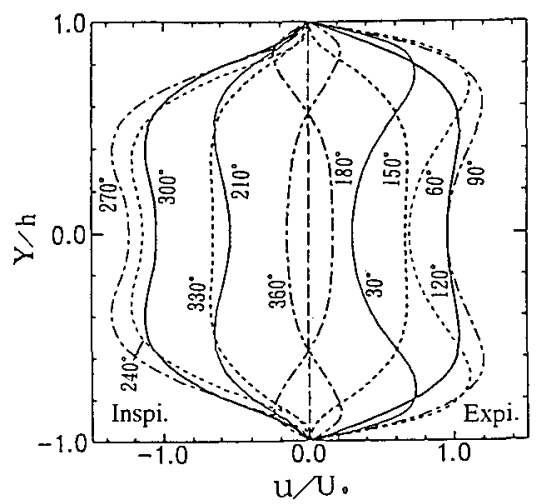

(b) $X / h=-0.334$

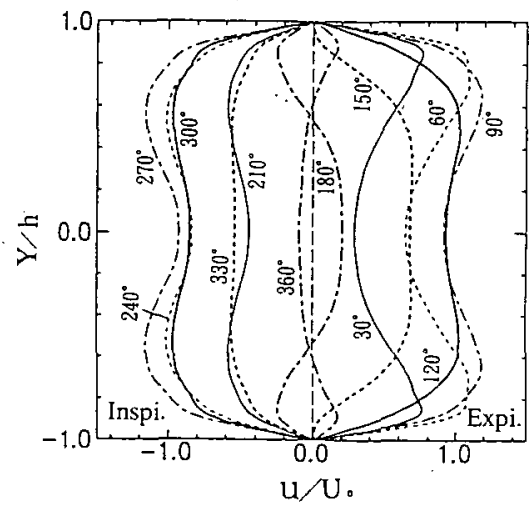

(c) $X / h=-0.000$

Fig.13 Time-dependent velocity profile $\alpha=4.84, R e=477, H / h=3$ 


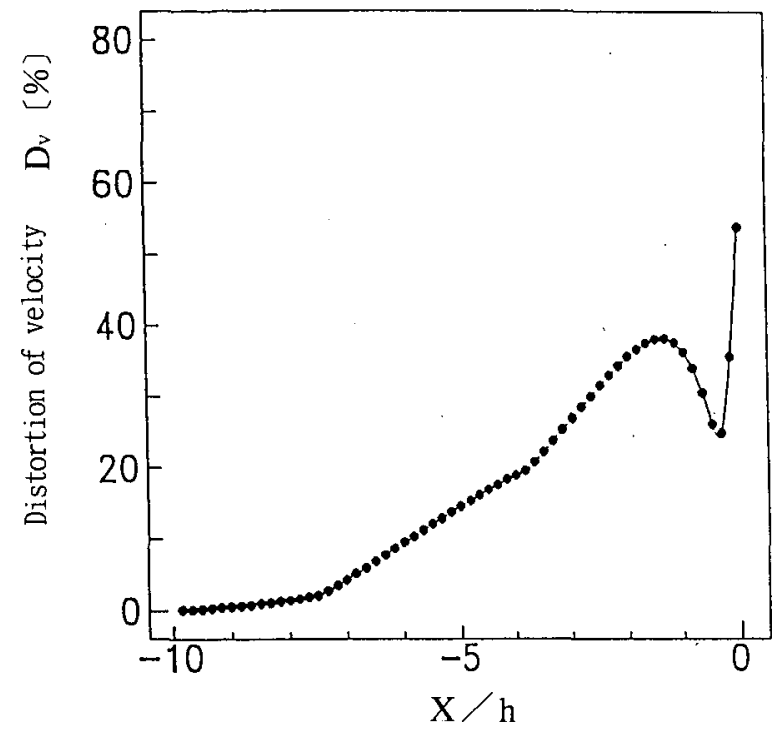

Fig.14 Distortion of velocity $\alpha=4.84, \operatorname{Re}=477, H / h=3$

脈動の 1 周期を通じた最大流速の差で流速の歪みを定義 して, $X / h$ に対して示したものがFig.14である.これに よると開口端に近づくにしたがって, 剝離渦の影響を強 くうけて昰みが $40 \%$ にも達している.脈動流のストロー $ク(s / h=10.2)$ と比較すると, 開口端の影響の扔よぶ 範囲はほぽストロークの大きさに等しく，それより上流 では開口端の影響は小さい。

以上の結果より，ストリーミングの強さは開口端近傍 では極めて強く，その範囲は脈動流のストロークの大き さにほ沽相当すると考元られる。

\subsection{3 脈動流の可視化}

ストリーミングの存在は空間の各点において流速を時 間平均することによっても調べることができるが，ガス 交換の観点からは流体粒子をラグランジュ的に追跡する ことが必要である。そこで，二つの可視化手法，すなわ ち粒子トレーサ法とタイムライン法を用いて調べる。

a 、粒子トレーサ法による可視化

まず，脈動流における強制的なガス交換の状態を視覚 的にとらえるために，粒子トレーサ法により流れを観察 した.

ダクト開口端およびダクト内の任意の位置において, ダクト幅 $(\mathrm{Y})$ 方向の格子点上で, ある 1 周期の間に下死 点を始点として $30^{\circ}$ の位相間隔で次々と粒子を発生させ, その後さらに脈動を繰り返したときに，粒子がどのよう に分散してゆくかを調べる。

Fig.15 は，そのようにしてえられた結果の1例で，粒 子発生後の各サイクルの吐き出し行程と吸い込み行程の 終点（上死点と下死点）における粒子の分散状態を示し たもので，脈動を繰り返しながら粒子が流れ場に広がっ てゆく様子がわかる。これを見ると，ダクト内に吸い込 まれた粒子は，ある距離まで達するとそれ以上ほとんど ダクト内部に進入することなく安定して脈動を繰り返す。
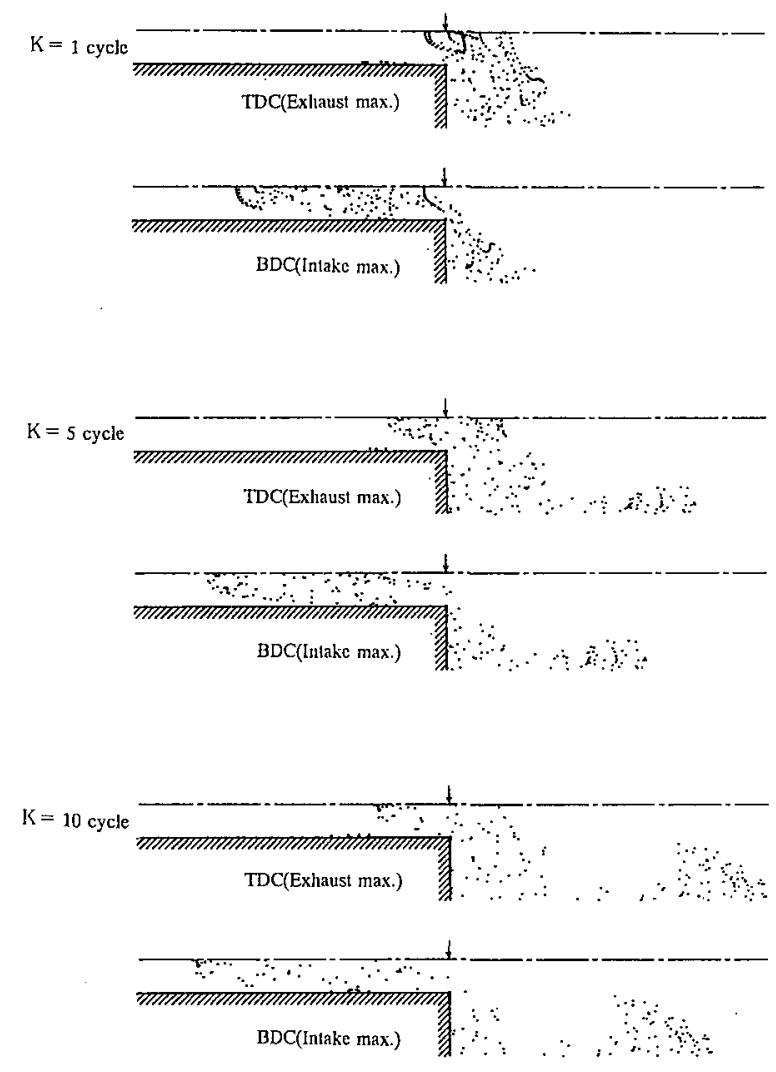

Fig.15 Distortion of velocity $\alpha=6.84, \operatorname{Re}=477, H / h=3$

これは，ダクト開口端の影響によるストリーミングがあ る範囲に限定されることによるものであって，ダクト内 部への粒子の到達距離はほほ派動流のストロークの大き さ $(s / h=5.10)$ に相当して扔り, 前述の流速䄳より推 論した結果と一致する。一方，ダクト開口端から下流に 放出された粒子の一部は，強いストリーミングに乗って 移動し，次第に下流に広がってゅく様子が観察される.

b.タイムライン法による可視化

粒子トレーサ法では，脈動によってガスが交換される 様子を見ることができたが，ガス交換量を定量的に調べ るために，流れの中にタイムラインを作り，それを時間 的に追跡するタイムライン法で可視化した。

Fig.16 は, 脈動流の吐き出し行程の始点（下死点, 位 相 0）の瞬間に開口端に直線状のタイムラインを発生さ せ，その動きを脈動 1 周期に渡って追跡したものである. これを見ると，タイムラインは開口端から吐き出される と開口端に生ずる渦に乗って次第に下流外側に広がって 行くが，吸い込み行程に入るとダクト中心側よりも壁面 側から強く吸い込まれている. その結果, タイムライン はキノコ状となり，吸い込み行程の終点においても初期 の直線状のタイムラインの位置に戻ることはない。

吸い込み行程の終点に扔けるタイムラインを調べると, 脈動 1 周期の間にダクト内の流体がダクトから下流に押 し出されている(Fig.16中のハッチ部)。結局, これだけ の量の流体がダクト内から下流に流出し，同量の流体が 

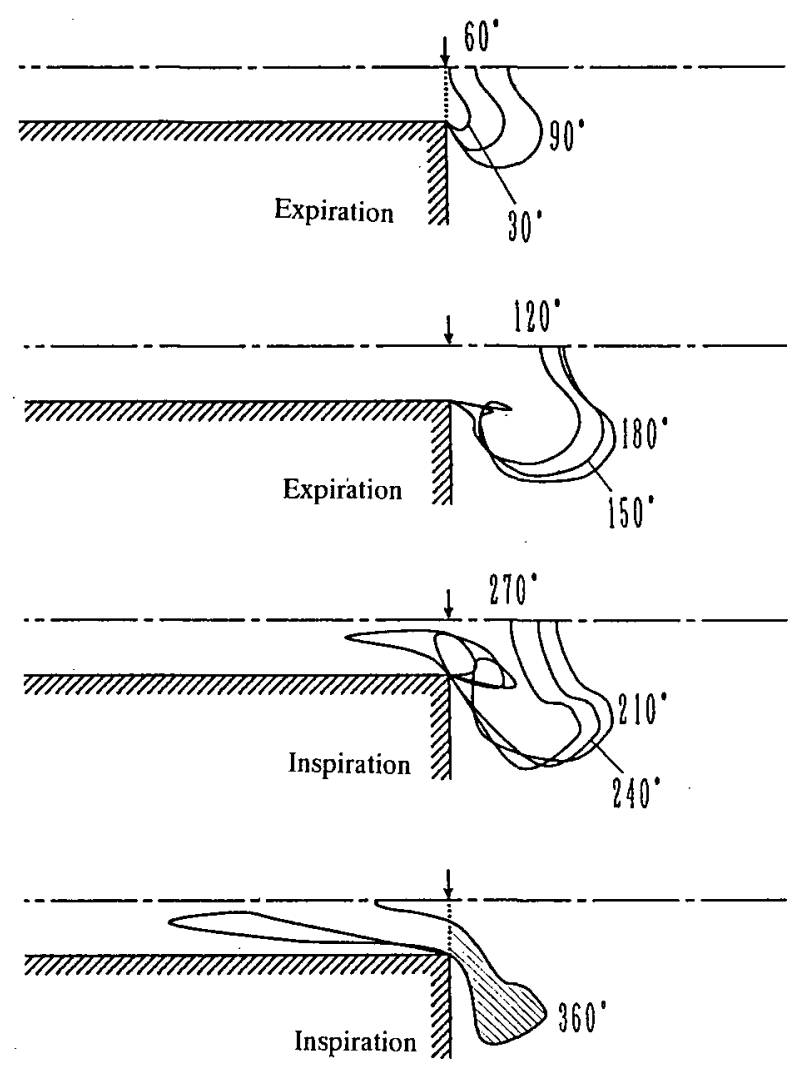

Fig.16 Extension of the particles around the intake $\alpha=6.84, R e=477, H / h=3$

ダクトの下流からダクト内に流入しているわけで，それ が脈動による強制的なガス交換量となる. 図の場合, 強 制的なガス交換量は脈動のストローク体積の約 $34 \%$ で ある．正常呼吸におけるガス交換効率は約 15\%であり， 高頻度呼吸においては効率はさらに悪いと考えられるか ら，鼻口のストリーミングによるガス交換が極めて効率 的であることがわかる. 一方, 呼吸器系を解析する際に は通常, 吸気行程において鼻口から新気を吸い込むとし て解析するが, 上記の結果は, 鼻口においてガス交換効 率を考慮する必要があることを示している。

\section{4.むすび}

開口端を有するダクトにおける脈動流の挙動を可視化 実験おるび数值解析で調べ, 次の結果を得た。

1) 脈動流の吐き出し行程に扔いて, ダクト開口端に一 対の渦が形成されるが, 吸入行程において, 渦の周囲 から外気がジェット状に吸い込まれて，流れは時間的， 空間的に非対称な変化をする.

2）これより，ダクト開口端まわりに強いストリーミン グが生じ，それによって強制的なガス交換が行われる。 これが呼吸におけるガス交換を助けていると考えられ る.
3 ）ダクト開口端がダクト内脈動流に影響をおよほす範 囲は，脈動のストローク程度であり，その範囲内でス トリーミングによってガスの混合が行われるが，それ より上流ではストリーミングは無視することができる. 最後に, 本研究に協力してくれた当時本学大学院生長 谷川正人，小林和典抢よび卒業研究生宮沢英樹, 丸山貴 和, 鈴木崇, 貝原英樹, 三島久明, 菊池孝幸, 橋本泰岳, 高橋宏，菊池原裕，大崎正道の諸氏に感謝いたします。

また，本研究は文部省科学研究補助金（重点領域研究 (1)，生体の機能と構造に関する計算バイオメカニクスの 「呼吸器系におけるガス交換に関する研究」を分担）の 交付を受け遂行されたものであって，ここに感謝の意を 表します。

\section{参考文献}

1) West, J. B. ed., Bioengineering Aspects of the Lung, Lung Biology in Health and Disease Vol.3, Dekker, 1977

2 ) Uchida, S., The Pulsating Viscous Flow Superposed on the Steady Laminar Motion of Incompressible Fluid in a Circular Pipe, ZAMP, VIl, 1956, 403

3 ）角田勝, 須藤浩三, 曲がり管内二次流れの可視化法, 可視化情 報, 10-29, 1990, 263.

4) Pedley, T. J. et al., Gas Flow and Mixing in Airways. 文 献(2), 163

5 ）鉿木滋雄, 分岐管における拍動流中の流れと拡散, 東京大学 修士論文, 1991

6) Haselton, F. R. \& Scherer, P. W., Flow Visualization of Steady Streaming in Oscillatory Flow through a Bifurcating Tube, J. Fluid Mech., 123, 1982, 315

7) Taylor, G. I., Dispersion of soluble Matter in Solvent Flowing Slowly through a Tube, Proc. Royal Soc. London. A219, 1953, 186

8 ) Watson, E. J., Diffusion in Oscillatory Pipe Flow, J. Fluid Mech., 133, 1983, 233

9) Joshi, C. H.et al., An Experimental Study of Gas Exchange in Laminar Oscillatory Flow. J. Fluid Mech. $133,1983,245$

10）西田, 藤岡, 小渡, 谷下, 振動流に発生する乱れのテーラー抎 散に対する影響，日本機械学会論文集（B 編） 58-555，1992, 3298-3304.

11) Scherer, P. W. et al., Gas Transport in Branched airways during High-Frequency Ventilation, Annals of Biomed. Engg., vol.12, 1984, 385-405

12）西田, 吉村, 谷下, 対称分岐管内振動流における軸方向拡散の 評価, 日本機械学会論文集 (B 編) 60-570, 1994, 417-424

13) Kamm, R. D. et al., High-Frequency Ventilation. CRC Critical Reviews in Biomed. Engg., 9 (4), 1984, 347

14) Yumino T.\& Tanida Y., A Computatinal Analysis of Gas Transport in Respiratory Network, Proceedings of the School of Engg. Tokai University, Vol.X X, 1995, 45-60

15) Gosman, A. D. et. al., Heat and Mass Transfer in Recirculating Flows, Academic Press, NY., 1969, 94 